\title{
Upaya Meningkatkan Hasil Belajar IPA Peserta Didik pada Masa Pandemi Covid-19 Melalui Project Based Learning di Kelas VI.C T.P. 2020/2021 SD Negeri 04 Payakumbuh
}

\author{
Zuharnelhas \\ SD Negeri 04 Payakumbuh \\ Jl. Ade Irma Suryani No.13, Labuh Baru, Kota Payakumbuh, Sumatera Barat, Indonesia \\ zuharnelhas@gmail.com
}

\begin{abstract}
Science learning is a learning content that is favored by students. Because the material is directly related to everyday life. Online learning causes students' interest in learning to decrease. So that the value of the science content obtained is low. It is hoped that the Project Based Learning model can help improve student learning outcomes in science learning content. The implementation of the Project Based Learning model consists of five activities, namely: determining basic questions, designing project plans, compiling schedules, monitoring students and project progress, testing results, evaluating experiences, finalizing, and publishing products. The data obtained are sourced from student data, teachers, and documentation. The data collection procedure used observation instruments, field notes, tests, peer observation, collaboration, and documentation. The results obtained can be seen from three sides. The first is from the implementation side related to the interest of students in carrying out learning shows an increase, secondly the formation of student character is reflected in the assignment of assignments, and third, there is an increase in students' science learning outcomes with the Project Based Learning model in class VI.C SD Negeri 04 Payakumbuh.
\end{abstract}

Keywords: Improving Science Learning Outcomes with Project Based Learning Model

\begin{abstract}
Abstrak
Pembelajaran IPA merupakan muatan pembelajaran yang digemari peserta didik. Karena materinya berkaitan langsung kehidupan sehari-hari. Pembelajar daring menyebabkan minat peserta didik menurun untuk belajar. Sehingga nilai muatan IPA yang diperoleh rendah. Maka diharapkan dengan model Project Based Learning dapat membantu meningkatkan hasil belajar peserta didik pada muatan pembelajaran IPA. Dalam pelaksanaan model Project Based Learning ini terdiri atas lima kegiatan, yakni: penentuan pertanyaan mendasar, mendesain perencanaan proyek, menyusun jadwal, memonitor peserta didik dan kemajuan proyek, menguji hasil, mengevaluasi pengalaman, finalisasi dan publikasi produk. Data yang diperoleh bersumber dari data peserta didik, guru, dan dokumentasi. Prosedur pengumpulan data menggunakan instrumen pengamatan, catatan lapangan, tes, pengamatan teman kolaborasi dan dokumentasi. Hasil yang diperoleh dapat kita lihat dari tiga sisi. Yang pertama dari sisi pelaksanaan yang berhubungan dengan minat peserta didik dalam melaksanakan pembelajaran menunjukan peningkatan, kedua pembentukan karakter peserta didik tergambar dari setoran tugas, dan ketiga, adanya peningkatan hasil belajar IPA peserta didik dengan model Project Based Learning di kelas VI.C SD Negeri 04 Payakumbuh.
\end{abstract}

Kata kunci: Peningkatan Hasil Belajar IPA Dengan Model Project Based Learning

Corresponding author: Zuharnelhas

Copyright (c) 2021 Zuharnelhas

Email Address: zuharnelhas@gmail.com (Jl. Ade Irma Suryani No.13, Labuh Baru, Kota Payakumbuh,)

Received 09 May 2021, Accepted 02 July 2021, Published 03 July 2021

\section{PENDAHULUAN}

Pendidikan merupakan upaya sadar yang dilakukan seseorang atau kelompok orang dalam usaha mendewasakan manusia melalui upaya pengajaran dan penugasan. Dalam proses kedewasaan manusia yang hidup dan berkembang, perubahan itu merupakan hasil belajar. Hal ini berarti bahwa dalam pendidikan terjadi sebuah proses pengubahan sikap dan tingkah laku.

Salah satu upaya untuk menjaga agar pembelajaran tetap berjalan pendidikan di sekolah adalah dengan cara perbaikan proses belajar mengajar atau pembelajaran Dalam upaya menjalankan proses 
pendidikan pada masa pandemic covid -19 sangat dibutuhkan kemampuan guru dalam kerancang pembelajaran. Berbagai konsep dan wawasan baru tentang pembelajaran di sekolah telah muncul dan berkembang seiring pesatnya ilmu pengetahuan dan teknologi. Guru sebagai pendidik yang menduduki posisi strategis dalam pengembangan sumber daya manusia, dituntut untuk terus mengikuti perkembangan konsep-konsep baru dalam dunia pendidikan

Matematika merupakan salah satu ilmu dasar. Karena matematika dipelajari pada setiap jenjang pendidikan. Mulai dari pendidikan sekolah dasar, sekolah menengah, sekolah lanjutan tingkat atas, dan sampai ke perguruan tinggi. Muatan pelajaran matematika merupankan pembelajaran yang berpola berfikir deduktif, dan konsisten. Sehingga materi pembelajaran pada muatan matematika bersifat berjenjang. Dengan demikian untuk belajar matematika harus melalui tahap demi tahap. Hal ini dilakukan karena materi demi materi saling terkait satu sama lainnya.

Pada kurikulum 2013 jenjang SD Kelas VI.C Matematika ini diajarkan dalam waktu 8 jam perminggu. Tidak semua materi yang dipelajari mudah dipahami peserta didik. Sehingga pada tahap tahap awal pengenalan konsep sangat membutuhkan metode yang bervariasi, agar peserta didik mudah untuk memahami konsep yang akan ditanamkan dalam pembelajaran. Hal ini dapat menghapuskan momok terhadap pelajaran matematika yang selama ini sangat ditakuti oleh banyak peserta didik.

Di SD Negeri 04 Payakumbuh pada Kelas VI.C tempat penulis bertugas, materi operasi penjumlahan bilangan bulat positif negatif ini sangat susah dimengerti oleh peserta didik. Terbukti dengan rendahnya nilai-nilai peserta didik pada setiap latihan maupun pada saat penilaian harian yang merupakan hasil belajar peserta didik. Pada materi KD 3.2 Menjelaskan dan melakukan penjumlahan dan pengurangan bilangan yang melibatkan bilangan bulat positif dan negatif dalam kehidupan seharihari, dengan KBM 80.

Pada hal materi melakukan penjumlahan bilangan yang melibatkan bilangan bulat positif negatif dalam kehidupan sehari-hari serta mengaitkan penjumlahan dan pengurangan sangatlah penting. Penjumlahan ini merupakan dasar untuk dapat melanjutkan pada materi selanjutnya pada tema selanjutnya diawal semester ganjil tahun pelajaran 2019/2020.

Rendahnya perolehan hasil belajar ini juga dipicu oleh kurang termotivasinya peserta didik dalam proses pembelajaran yang dilaksanakan. Sehingga peserta didik sering bermaian dalam belajar. Tidak merespon proses pembelajaran. Sering tidak membuat tugas rumah yang diberikan guru. Bahkan banyak peserta didik yang tidak mampu menyelesaikan soal-soal tepat pada waktunya dengan benar. Sehingga nilai-nilai latihan serta penilaian harian mereka tidak mencapai KBM yang telah ditetapka

Penggunaan metode pembelajaran yang tidak bervariasi. Kurang kreatifnya guru dalam merancang dan melaksanakan proses pembelajaran yang monoton. Pembelajaran yang tidak menggunaan media yang menarik, juga merupakan penyebab rendahnya nilai hasil belajar peserta didik kelas VI.C ini. Berdasarkan latar beakang masalah diatas tujuan penelitian ini adalah untuk membahas dan mendapatkan informasi tentang upaya meningkatkan hasil belajar matematika peserta didik melalui permaian kartu merah putih di kelasVI.C SD Negeri 04 Payakumbuh. 
Belajar pada hakekatnya adalah proses interaksi terhadap semua situasi yang ada disekitar individu. Belajar dapat dipandang sebagai proses diarahkan kepada tujuan dan proses berbuat melalui pengalaman. belajar juga merupakan proses melihat, mengamati, dan memahami sesuatu (Sudjana,1998:28). Belajar bermakna suatu proses dikaitkannya informasi baru pada konsep-konsep relevan yang terdapat dalam struktur kognitif seseorang. Belajar adalah modifikasi atau memperteguh kelakuan melalui pengalaman (learning is defined the modification or streng modifcation or strenghening of behavior through experiencing). Menurut pengertian ini, belajar merupakan proses, suatu kegiatan bukan suatu hasil atau tujuan. Belajar bukan hanya mengingat, akan tetapi lebih luas dari itu yakni mengalami. Hasil belajar bukan hanya mengingat suatu penguasaan hasil latihan melainkan pengubahan kelakuan (Hamalik, 2004).

Pengertian belajar dapat didefinisikan sesuai dengan nilai filosofi yang dianut dan pengalaman para ilmuan atau pakar itu sendiri dalam membelajarakan para peserta didikanya. Belajar merupakan suatu proses dimana suatu organisasi berubah perilakunya sebagai akibat pengalaman. Muhammad Ali dalam Hanafiah dan Suhana (2011:5) menyatakan, pengertian belajar maupun yang dirumuskan para ahli antara yang satu dengan yang lainnya terdapat perbedaan. Belajar didefinisikan sebagai suatu proses dimana suatu organisasi berubah prilakunya sebagai akibat pengalaman dalam Dahar (2011:2).

Secara sederhana Anthony Robbins, mendefenisikan belajar sebagai proses menciptakan hubungan antara sesuatu (pengetahuan) yang sudah dipahami dan sesuatu (pengetahuan) yang baru. Dari defenisi ini dimensi belajar memuat beberapa unsur, yaitu: (1) penciptaan hubungan, (2) sesuatu hal (pengetahuan) yang sudah dipahamai, dan (3) sesuatu pengetahuan yang baru. Jadi dalam makna belajar, di sini bukan berangkat dari sesuatu yang benar-benar belum diketahui, tetapi merupakan keterkaitan dari dua pengetahuan yang sudah ada dengan pengetahuan baru (Trianto, 2012).

Dari pendapat para ahli diatas dapat disimpulkan bahwa belajar adalah suatu proses perubahan tingkah laku yang sedang berlangsung secara bertahap yang terjadi sebagai suatu hasil dari latihan dan pengalaman.

Sudjana (2005) mengatakan bahwa penilaian hasil belajar adalah proses pemberian nilai terhadap hasil-hasil belajar yang dicapai peserta didik dengan kriteria tertentu. Dimyati dan Mudjiono (2006) mengemukakan pendapatnya tentang hasil belajar adalah hasil yang dicapai dalam bentuk angka-angka atau skor setelah diberikan tes hasil belajar pada setiap akhir pembelajaran. Nilai yang diperoleh peserta didik menjadi acuan untuk melihat penguasaan peserta didik dalam menerima materi pelajaran.

Pendapat Djamarah dan Zain (2006) tentang pengertian hasil belajar adalah apa yang diperoleh peserta didik setelah dilakukan aktifitas belajar. Hamalik (2008) memberikan pengertian hasil belajar sebagai terjadinya perubahan tingkah laku pada diri seseorang yang dapat di amati dan di ukur bentuk pengetahuan, sikap dan keterampilan. Perubahan tersebut dapat di artikan sebagai terjadinya peningkatan dan pengembangan yang lebih baik sebelumnya yang tidak tahu menjadi tahu. 
Dengan memahami pendapat para ahli diatas tentang pengertian hasil belajar, penulis sepaham bahwa hasil belajar dapat diartikan sebagai isyarat bahwa objek yang dinilai adalah hasil belajar peserta didik. Hasil belajar peserta didik pada hakikatnya merupakan perubahan tingkah laku setelah melalui proses belajar mengajar.

Dalam membelajarkan matematika guru hendaknya lebih memilih berbagai variasi pendekatan, strategi, metode yang sesuai dengan situasi sehingga tujuan pembelajaran yang direncanakan akan tercapai.Berdasarkan Permendiknas no 22 tahun 2006 bertujuan agar peserta didik memiliki kemampuan untuk Memahami konsep Matematika, menjelaskan keterkaitan antar konsep dan mengaplikasikan konsep secara luwes, akurat, efesien,dan tepat dalam pemecahan masalah.

Perkembangan pesat di bidang teknologi informasi dan komunikasi dewasa ini dilandasi oleh perkembangan matematika dibiadang teori bilangan, aljabar, analisis, teori peluang dan matematika diskrit. Untuk mengusasi dan mencipta teknologi di masa depan diperlukan penguasaan matematika yang kuat sejak dini.

Muatan Pembelajaran Matematika perlu diberikan kepada semua peserta didik mulai dari sekolah dasar untuk membekali peserta didik dengan kemampuan berpikir logis, analitis, sistematis, kritis, dan kreatif, serta kemampuan bekerjasama. Kompetensi tersebut diperlukan agar peserta didik dapat memiliki kemampuan memperoleh, mengelola, dan memanfaatkan informasi untuk bertahan hidup pada keadaan yang selalu berubah, tidak pasti, dan kompetitif.

Bermain menurut Piaget (1951) merupakan kegiatan yang dilakukan berulang-ulang demi kesenangan. Sedangkan menurut pendapat Elizabeth Hurlock (1987) bermain merupakan setiap kegiatan yang dilakukan dengan kesenangan tanpa memikirkan hasil akhir. Pada definisi umumnya, dalam term psikologi, didefinisikan oleh Joan Freeman dan Utami Munandar (1991) bahwa bermain adalah suatu aktifitas yang membantu anak mencapai perkembangan yang utuh baik segi fisik, moral, intelektual, sosial dan emosional.

Mulyadi (2004) memberikan 5 definisi tentang bermain, yaitu: 1. Sesuatu yang menyenangkan dan memiliki nilai intrinstik pada anak, 2. Tidak meiliki tujuan ekstrinsik, motivasinya lebih bersifat intrinsic, 3. Bersifat spontan dan sukarela, tidak ada unsur keterpaksaan dan bebas dipilih oleh anak, 4 . Melibatkan peran aktif keikut sertaan anak, 5. Memiliki hubungan sistematik yang khusus dengan sesuatu yang bukan bermain, seperti kreativitas, pemecahan masalah, belajar Bahasa, perkembangan sosial dan sebagainya.

Dari beberapa pengertian diatas dapat disimpulkan bahwa bermain atau permainan adalah suatu kegiatan yang menimbulkan keasyikan dan kesenangan untuk melepaskan energi yang dilakukan secara suka rela tanpa paksaan dan rasa tanggungjawab, dan tanpa mempertimbangkan hasil akhir yang berfungsi sebagai pengembangan potensi dan kreatifitas anak. (dyanrch)

Kartu Kata Bergambar Menurut Kamus Besar Bahasa Indonesia kartu adalah kertas tebal berbentuk persegi panjang. Sedangkan kata adalah unsur bahasa yang diucapkan atau dituliskan yang merupakan perwujudan kesatuan perasaan dan pikiran yang dapat digunakan dalam berbahasa. Gambar 
merupakan media yang paling umum dipakai. Dia merupakan bahasa 16 yang umum, yang dapat dimengerti dan dinikmati di mana-mana.

Kartu kata bergambar ini akan menjadi media yang nantinya saat pembelajaran, peserta didik akan menemui macam-macam kartu yang berbeda tulisan serta gambarnya. Dan dalam penggunaannya bisa divariasikan dengan kartu kalimat dan kartu huruf. Adapun kelebihan dalam kartu kata bergambar menurut (Dina Indriana, 2011: 69), yaitu: ayam betina 17 1) Mudah dibawa ke mana-mana. 2)Praktis dalam membuat dan menggunakannya, sehingga kapan pun anak didik bisa belajar dengan baik menggunakan media ini. 3)Gampang diingat karena kartu ini bergambar yang sangat menarik perhatian. 4)Menyenangkan sebagai media pembelajaran, bahkan bisa digunakan dalm permainan.

Surachman (1996: 28) menyatakan bahwa media kartu bergambar mampu meningkatkan perhatian, minat, meningkatkan daya kreasi, membuat isi pelajaran tidak mudah terlupakan, dan membuat proses belajar atau komunikasi berjalan lancar. Media kartu bergambar merupakan salah satu media visual bergambar yang mudah dimengerti dan dipahami peserta didik. Oleh karena itu penggunaan media kartu bergambar akan meningkatkan motivasi peserta didik dan kemampuan menerima materi pelajaran yang diberikan.

\section{METODE}

\section{Setting Penelitian}

Penelitian ini merupakan penelitian tindakan kelas. Penelitian ini bertempat di SD Negeri 04 Payakumbuh. Objek dalam penelitian ini adalah muatan pembelajaran Matematika dengan materi operasi penjumlahan bilangan bulat positif negatif di kelas VI.C SD Negeri 04 Payakumbuh Kecamatan Payakumbuh Utara. Penelitian ini dilaksanakan selama satu semester dimulai dari bulan Juli sampai pada bulan Desember tahun pelajaran 2019/2020. Prosedur penelitian terdiri dari tiga siklus dengan empat tahap penelitian yaitu perencanaan, pelaksanaan, observasi dan refleksi. Pengumpulan data dalam penelitian ini dilakukan dengan menggunakan teknik catatan lapangan, lembar kerja peserta didik, tes tertulis, lembaran observasi peserta didik, lembaran observasi guru dan dokumen pembelajaran. Pada penelitian ini menggunakan tehnik analisis deskriptif kualitatif dengan menggunakan rumus persentase.

\section{HASIL DAN DISKUSI}

\section{Siklus I}

a. Perencanaan

Pengembangan budaya literasi di sekolah SDN Gladak Anyar IV Pamekasan Keberhasilan pengembangan budaya literasi Pamekasan tercermin dari tumbuhnya minat baca anak. Ketika minat baca siswa meningkat, mereka dapat melihat bahwa anak-anak mereka bahagia, penyayang, atau berminat membaca. Dia juga menjelaskan bahwa cinta adalah apa yang disukai dan dicintai orang. Jadi, jika orang tersebut melakukan sesuatu yang penting baginya, dia akan bahagia tanpa hambatan dari luar 
(Sardiman, 2009). Menurut pengamatan peneliti, siswa SDN Gladak Anyar IV Pamekasan terlihat antusias, energik, gembira dan antusias saat mengikuti program literasi sekolah. Ini menunjukkan bahwa anak-anak bersemangat untuk melanjutkan proses literasi. Ini didasarkan pada visi Slamet dan menunjukkan beberapa indikator tentang apa yang ingin Anda lakukan, termasuk kesenangan, minat, penerimaan, dan keterlibatan siswa (Sardiman, 2009).

b. Pelaksanaan

Peretemuan pertama dilaksanakn pada tanggal 30 Juli 2019 dengan materi Penjumlahan bilangan bulat positif negatif. Pada tahap pelaksanaan terdri dari tiga tahapan yaitu kegiatan awal, kegiatan inti dan kegiatan penutup.

c. Observasi

Data pelaksanaan tindakan penelitian diperoleh berupa nilai hasil belajar peserta didik. Hasil belajar ini berasal dari tes formatif yang dilakukan pada akhir kegiatan pembelajaran. Berdasarkan hasil tes peserta didik dianalisa pencapaian rata-rata serta persentase ketuntasan yang diperoleh pada setiap siklus. Hasil observasi pengamatan terhadap guru dan peserta didik dilakukan pada setiap siklus, juga menentukan keberhasilan penelitian ini. Berdasarkan hasil observasi didapat data bahwa factor peserta didik dan guru sangat berpengaruh pada keberhasilan penelitian ini.

Untuk mengetahui hasil belajar peserta didik setelah dilaksanakan perbaikan proses pembelajaran, peserta didik mengerjakan soal tes. Berdasarkan hasil tes penulis memperoleh data siklus pertama berupa nilai yang tergambar pada tabel dibawah ini:

Tabel 1. Nilai Siklus 1 KD 3.2 Matematika indikator 3.2.1 Semester 1 Kelas VI.C SD Negeri 04 Payakumbuh Kecamatan Payakumbuh Utara

\begin{tabular}{|c|c|c|c|c|}
\hline \multirow{2}{*}{ No } & \multirow{2}{*}{ Nama Peserta Didik } & \multirow{2}{*}{ Nilai } & \multicolumn{2}{|c|}{$\begin{array}{c}\text { Indikator } \\
\text { Keberhasilan }\end{array}$} \\
\hline & & & Tercapai & Tidak \\
\hline 1 & ADH & 70 & & $\sqrt{ }$ \\
\hline 2 & ALF & 50 & & $\sqrt{ }$ \\
\hline 3 & ALI & 60 & & $\sqrt{ }$ \\
\hline 4 & ARR & 80 & $\sqrt{ }$ & \\
\hline 5 & BRI & 80 & $\sqrt{ }$ & \\
\hline 6 & CHE & 80 & $\sqrt{ }$ \\
\hline 7 & DAF & 60 & & \\
\hline 8 & FIKR & 90 & $\sqrt{ }$ & \\
\hline 9 & GAL & 80 & $\sqrt{ }$ & $\sqrt{ }$ \\
\hline 10 & GIL & 60 & & $\sqrt{ }$ \\
\hline 11 & HAN & 70 & & $\sqrt{ }$ \\
\hline 12 & JIH & 70 & & $\sqrt{ }$ \\
\hline 13 & KEY & 80 & & $\sqrt{ }$ \\
\hline 14 & LAR & 30 & & \\
\hline 15 & MAR & 90 & & \\
\hline 16 & MEY & 70 & & \\
\hline 17 & MFA & 60 & & \\
\hline 18 & MRI & 70 & & \\
\hline
\end{tabular}




\begin{tabular}{|c|c|c|c|c|}
\hline 19 & MYU & 50 & & $\sqrt{ }$ \\
\hline 20 & M.ZA & 80 & $\sqrt{ }$ & \\
\hline 21 & NAJ & 80 & $\sqrt{ }$ & \\
\hline 22 & NAS & 70 & & $\sqrt{ }$ \\
\hline 23 & NAU & 60 & & $\sqrt{ }$ \\
\hline 24 & NUR & 40 & & $\sqrt{ }$ \\
\hline 25 & NAZ & 70 & & $\sqrt{ }$ \\
\hline 26 & NID & 80 & $\sqrt{ }$ & \\
\hline 27 & QAN & 80 & $\sqrt{ }$ & \\
\hline 28 & REV & 40 & & $\sqrt{ }$ \\
\hline 29 & SHE & 30 & & $\sqrt{ }$ \\
\hline 30 & SIT & 60 & & $\sqrt{ }$ \\
\hline 31 & TAL & 50 & & $\sqrt{ }$ \\
\hline 32 & VEN & 80 & $\sqrt{ }$ & \\
\hline 33 & WAZ & 50 & & $\sqrt{ }$ \\
\hline \multirow[t]{3}{*}{34} & YUD & 50 & & $\sqrt{ }$ \\
\hline & JUMLAH & 2220 & 12 & 22 \\
\hline & RATA-RATA & 65.29 & $35,29 \%$ & $64,71 \%$ \\
\hline
\end{tabular}

Dari tabel nilai peserta didik diatas dapat kita simpulkan bahwa rata-rata nilai siklus pertama diperoleh 65,29 dengan 35,29\% peserta didik mencapai indikator keberhasilan dan 64,71\% peserta didik belum mencapai indikator keberhasilan.

Tabel 2. Rentangan Nilai yang Diperoleh peserta didik Siklus Pertama

\begin{tabular}{|l|c|c|}
\hline No & Nilai & Hasil Yang Diperoleh \\
\hline 1. & $0-60$ & 15 \\
\hline 2. & $61-70$ & 7 \\
\hline 3. & $71-80$ & 10 \\
\hline 4. & $81-90$ & 2 \\
\hline 5. & $91-100$ & 0 \\
\hline
\end{tabular}

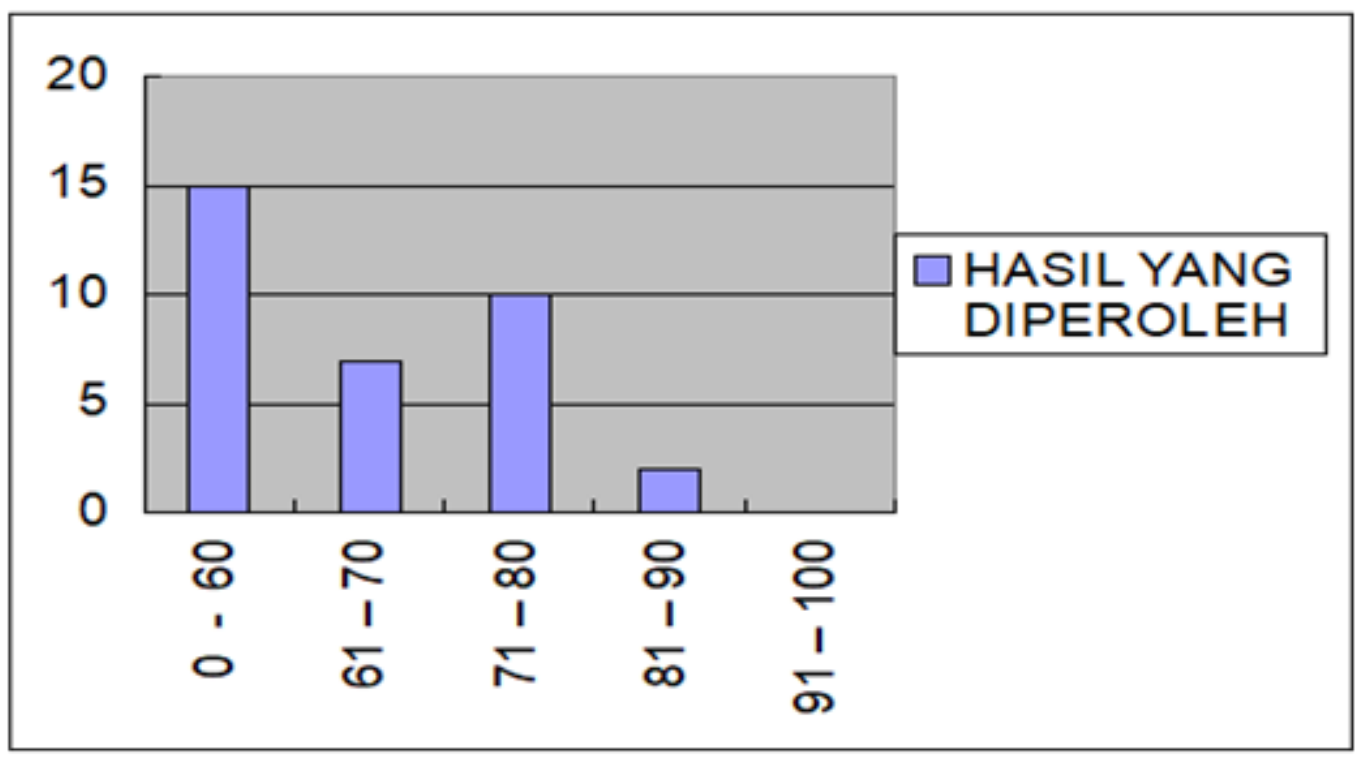

Gambar 1. Perolehan Nilai tes pada siklus 1 


\section{d. Refleksi}

Disaat melakukan refleksi, peneliti dengan teman kolaborasi melakukan pengamatan untuk membahas keberhasilan dan kendala yang dilakukan pada siklus pertama. Hal-hal yang ditemukan pada siklus pertama diantaranya peserta didik kurang antusias dalam menerima informasi yang disampaikan guru. Ini disebabkan karena kurang jelasnya slide yang ditampilkan guru di papan tulis. Sehingga peserta didik tidak termotivasi dalam memberikan pertanyaan dan jawaban dari pertanyaan yang diajukan guru ataupun oleh peserta didik lain.

Peserta didik sebagian besar tidak memiliki keberanian dalam berbicara, mengemukakan hasil diskusinya dalam kelompok. peserta didik tidak fokus dalam belajar, bahkan cendrung ribut. Karena peserta didik belum terbiasa dalam berdiskusi. Sementara kegitan pembelajaran lebih didominasi oleh guru.

Penjumlahan dan pengurangan pada mutan pelajaran Matematka Kelas VI SD Negeri 04 Payakumbuh Kecamatan Payakumbuh Utara dengan media kartu merah putih dapat disimpulkan bahwa:

1. Rata-rata nilai peserta didik 65,29

2. Peserta didik yang memperoleh nilai 80 keatas 12 orang dari 34 orang peserta didik. Artinya baru 35,29\% peserta didik yang mencapai indikator keberhasilan.

Berdasarkan hasil analisa data rata-rata nilai yang diperoleh 65,29 dengan 35,29\% peserta didik mencapai indikator keberhasilan dan 64,71\%, maka perlu dilakukan siklus ke dua pada penelitian tindakan kelas ini, dengan merevisi kekurangan serta kelemahan yang terjadi pada siklus pertama.

\section{Siklus II}

a. Perencanaan

Pada tahap ini peneliti mempersiapkan perangkat pembelajaran yang terdiri dari rencana pelajaran 2, LKS 2, soal tes penilaian harian 3, dan alat-alat pengajaran yang mendukung.

b. Pelaksanaan

Pertemuan siklus kedua dilaksanakan pada tanggal 8 Agustus 2019 dengan materi operasi pengurangan bilangan bulat positif negatif. Pada tahapan ini terdiri dari 3 kegiatan yaitu, kegiatan awal, kegiatan inti dan kegiatan penutup.

c. Observasi

Pelaksanaan siklus kedua yang dilaksanakan oleh peneliti bersama dengan teman kolaborasi dengan materi KD 3.2. Indikator 3.2.2 tentang operasi hitung pengurangan bilangan bulat positf dan bilangan bulat negatif pada muatan pelajaran matematika dengan menggunakan media kartu merah putih. Hasil analisa data pada siklus kedua dapat diperoleh nilai tes siklus kedua pada tabel dibawah ini sebagai berikut: 
Tabel 3. Nilai Siklus 2 KD 3.2 Matematika indikator 3.2.2 Semester 1 Kelas VI.C SD Negeri 04 Payakumbuh Kecamatan Payakumbuh Utara

\begin{tabular}{|c|c|c|c|c|}
\hline \multirow[t]{2}{*}{ No } & \multirow{2}{*}{ Nama Peserta Didik } & \multirow{2}{*}{ Nilai } & \multicolumn{2}{|c|}{$\begin{array}{c}\text { Indikator } \\
\text { Keberhasilan }\end{array}$} \\
\hline & & & Tercapai & Tidak \\
\hline 1 & $\mathrm{ADH}$ & 80 & $\sqrt{ }$ & \\
\hline 2 & ALF & 50 & & $\sqrt{ }$ \\
\hline 3 & ALI & 60 & & $\sqrt{ }$ \\
\hline 4 & ARR & 80 & $\sqrt{ }$ & \\
\hline 5 & BRI & 80 & $\sqrt{ }$ & \\
\hline 6 & $\mathrm{CHE}$ & 80 & $\sqrt{ }$ & \\
\hline 7 & DAF & 90 & $\sqrt{ }$ & \\
\hline 8 & FIKR & 100 & $\sqrt{ }$ & \\
\hline 9 & GAL & 80 & $\sqrt{ }$ & \\
\hline 10 & GIL & 60 & & $\sqrt{ }$ \\
\hline 11 & HAN & 80 & $\sqrt{ }$ & \\
\hline 12 & $\mathrm{JIH}$ & 80 & $\sqrt{ }$ & \\
\hline 13 & KEY & 100 & $\sqrt{ }$ & \\
\hline 14 & LAR & 50 & & $\sqrt{ }$ \\
\hline 15 & MAR & 100 & $\sqrt{ }$ & \\
\hline 16 & MEY & 80 & $\sqrt{ }$ & \\
\hline 17 & MFA & 60 & & $\sqrt{ }$ \\
\hline 18 & MRI & 60 & & $\sqrt{ }$ \\
\hline 19 & MYU & 50 & 5 & $\sqrt{ }$ \\
\hline 20 & M.ZA & 80 & $\sqrt{ }$ & \\
\hline 21 & NAJ & 80 & $\sqrt{ }$ & \\
\hline 22 & NAS & 80 & $\sqrt{ }$ & \\
\hline 23 & NAU & 60 & & $\sqrt{ }$ \\
\hline 24 & NUR & 40 & & $\sqrt{ }$ \\
\hline 25 & NAZ & 80 & $\sqrt{ }$ & \\
\hline 26 & NID & 80 & $\sqrt{ }$ & \\
\hline 27 & QAN & 90 & $\sqrt{ }$ & \\
\hline 28 & REV & 60 & & $\sqrt{ }$ \\
\hline 29 & SHE & 50 & & $\sqrt{ }$ \\
\hline 30 & SIT & 60 & & $\sqrt{ }$ \\
\hline 31 & TAL & 50 & & $\sqrt{ }$ \\
\hline 32 & VEN & 80 & $\sqrt{ }$ & \\
\hline 33 & WAZ & 50 & & $\sqrt{ }$ \\
\hline 34 & YUD & 50 & & $\sqrt{ }$ \\
\hline & JUMLAH & 2410 & 19 & 15 \\
\hline & RATA-RATA & 70.88 & $55,88 \%$ & $44,12 \%$ \\
\hline
\end{tabular}

Dengan membaca tabel nilai yang diperoleh peserta didik pada siklus kedua diperoleh rata-rata 70,88 peserta didik yang mencapai indikator keberhasilan 55,88 \% dan yang tidak mencapai indikator keberhasilan $44,12 \%$. 
Tabel 4. Rentangan Nilai yang Diperoleh Peserta Didik Pada Siklus Kedua

\begin{tabular}{|c|c|c|}
\hline No & Nilai & Hasil yang Diperoleh \\
\hline 1. & $0-60$ & 15 \\
\hline 2. & $61-70$ & 0 \\
\hline 3. & $71-80$ & 15 \\
\hline 4. & $81-90$ & 2 \\
\hline 5. & $91-100$ & 2 \\
\hline
\end{tabular}

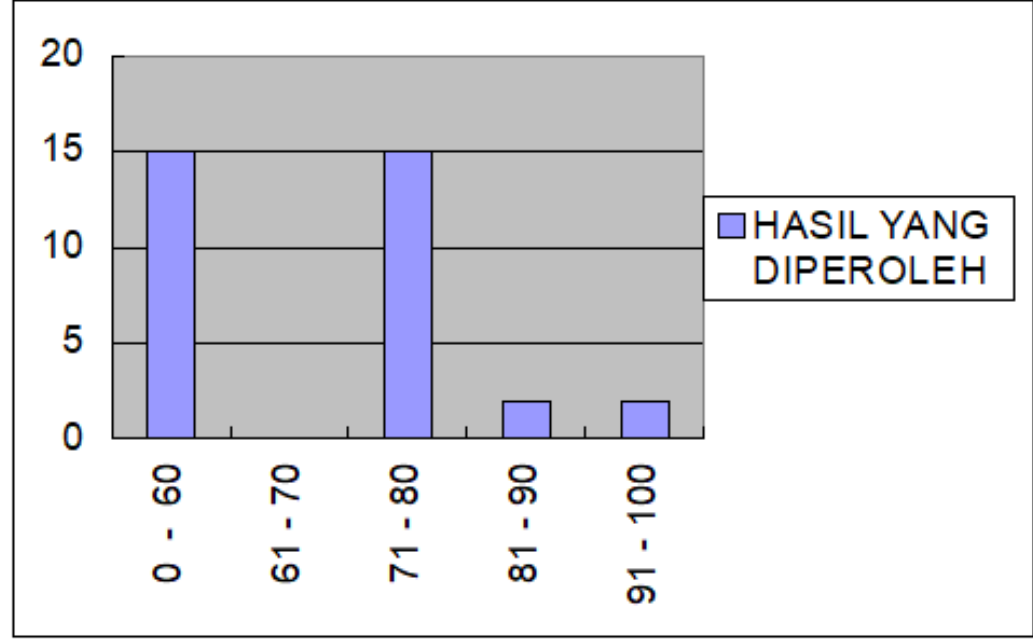

Gambar 2. Perolehan Nilai tes pada siklus 2

\section{d. Refleksi}

Berdasarkan hasil analisa pelaksanaan siklus kedua yang dilaksanakan dengan pengamatan penulis bersama teman kolaborasi bahwa pembelajaran pada siklus kedua perlu perbaikan, maka perlu dilakukan siklus ke tiga pada penelitian tindakan kelas ini, dengan menggunakan media kartu merah putih yang membantu mereka menyelesaikan operasi hitung bilangan bulat positif negatif. Ketekunan peserta didik dalam menyelesaikan setiap soal latihan belum tergambar tergambar pada proses pembelajaran. Pembelajaran yang berlangsung masih berpusat pada guru. Dalam kerja kelompok yang dilakukan peserta didik, masih perlu bimbingan guru sehingga peserta didik menunjukan keaktifan dalam pembelajaran. Sehingga setiap anggota kelompok dapat bekerjasama dalam menyelesaikan permasalahan yang dibahas kelompoknya.

Keberanian untuk mengemukakan pendapatpun masih perlu dibangun agar peserta didik memiliki kepercayaan diri dalam menyelesaikan soal dengan benar. Sehingga dapat diambil kesimpulan pelaksanaan penelitian tindakan kelas pada materi operasi hitung bilangan bulat positif negatif dengan menggunakan media kartu merah putih di kelas VI.C SDN 04 Payakumbuh masih perlu dilanjutkan ke siklus ketiga.

\section{Siklus III}

a. Perencanaan

Pada tahap ini peneliti mempersiapkan perangkat pembelajaran yang terdiri dari rencana pelajaran KD 3.2. Indikator 3.2.5. Dengan mengunakan LKS 3, soal tes penilaian harian 5, dan alat-alat 
pengajaran yang mendukung.

b. Pelaksanaan

Pertemuan pertama dilaksanakan pada tanggal 24 Agustus 2019 dengan materi operasi hitung campuran yang melibatkan bilangan bulat negatif dalam kontek sehari-hari. Pada tahapan ini terdiri dari 3 kegiatan yaitu, kegiatan awal, kegiatan inti dan kegiatan penutup.

c. Observasi

Pelaksanaan siklus ketiga yang dilaksanakan oleh peneliti bersama dengan teman kolaborasi dengan materi KD 3.2 indikator 3.2.5. tentang operasi hitung campuran yang melibatkan bilangan bulat negatif dalam kontek sehari-hari pada muatan pelajaran matematika dengan menggunakan media kartu merah putih telah menggambarkan keberhasilan. Hasil analisa data pada siklus ketiga dapat diperoleh nilai tes siklus ketiga pada tabel dibawah ini sebagai berikut:

Tabel 5. Nilai Siklus 3 KD 3.2 Matematika indikator 3.2.5 Semester 1 Kelas VI.C SD Negeri 04 Payakumbuh Kecamatan Payakumbuh Utara

\begin{tabular}{|c|c|c|c|c|}
\hline \multirow[t]{2}{*}{ No } & \multirow{2}{*}{ Nama Peserta Didik } & \multirow{2}{*}{ Nilai } & \multicolumn{2}{|c|}{$\begin{array}{c}\text { Indikator } \\
\text { Keberhasilan }\end{array}$} \\
\hline & & & Tercapai & Tidak \\
\hline 1 & $\mathrm{ADH}$ & 80 & $\sqrt{ }$ & \\
\hline 2 & ALF & 80 & $\sqrt{ }$ & \\
\hline 3 & ALI & 80 & $\sqrt{ }$ & \\
\hline 4 & ARR & 80 & $\sqrt{ }$ & \\
\hline 5 & BRI & 80 & $\sqrt{ }$ & \\
\hline 6 & CHE & 80 & $\sqrt{ }$ & \\
\hline 7 & DAF & 100 & $\sqrt{ }$ & \\
\hline 8 & FIKR & 100 & $\sqrt{ }$ & \\
\hline 9 & GAL & 80 & $\sqrt{ }$ & \\
\hline 10 & GIL & 80 & $\sqrt{ }$ & \\
\hline 11 & HAN & 80 & $\sqrt{ }$ & \\
\hline 12 & JIH & 80 & $\sqrt{ }$ & \\
\hline 13 & KEY & 100 & $\sqrt{ }$ & \\
\hline 14 & LAR & 60 & & $\sqrt{ }$ \\
\hline 15 & MAR & 100 & $\sqrt{ }$ & \\
\hline 16 & MEY & 100 & $\sqrt{ }$ & \\
\hline 17 & MFA & 80 & $\sqrt{ }$ & \\
\hline 18 & MRI & 80 & $\sqrt{ }$ & \\
\hline 19 & MYU & 60 & & $\sqrt{ }$ \\
\hline 20 & M.ZA & 80 & $\sqrt{ }$ & \\
\hline 21 & NAJ & 80 & $\sqrt{ }$ & \\
\hline 22 & NAS & 80 & $\sqrt{ }$ & \\
\hline 23 & NAU & 80 & $\sqrt{ }$ & \\
\hline 24 & NUR & 60 & & $\sqrt{ }$ \\
\hline 25 & NAZ & 80 & $\sqrt{ }$ & \\
\hline 26 & NID & 80 & $\sqrt{ }$ & \\
\hline 27 & QAN & 100 & $\sqrt{ }$ & \\
\hline 28 & REV & 80 & & $\sqrt{ }$ \\
\hline 29 & SHE & 60 & & $\sqrt{ }$ \\
\hline 30 & SIT & 80 & $\sqrt{ }$ & \\
\hline
\end{tabular}


Upaya Meningkatkan Hasil Belajar IPA Peserta Didik pada Masa Pandemi Covid-19 Melalui Project Based Learning di Kelas VI.C T.P. 2020/2021 SD Negeri 04 Payakumbuh, Zuharnelhas

\begin{tabular}{|l|c|c|c|c|}
\hline 31 & TAL & 80 & $\sqrt{ }$ & \\
\hline 32 & VEN & 80 & $\sqrt{ }$ & \\
\hline 33 & WAZ & 80 & $\sqrt{ }$ & \\
\hline 34 & YUD & 60 & & $\sqrt{ }$ \\
\hline & JUMLAH & 2740 & 28 & 6 \\
\hline & RATA-RATA & 80.59 & $82,35 \%$ & $17,65 \%$ \\
\hline
\end{tabular}

Dengan membaca tabel nilai yang diperoleh peserta didik pada siklus ketiga diperoleh rata-rata 80,59 peserta didik yang mencapai indikator keberhasilan 82,35\% dan yang tidak 17, $65 \%$.

Tabel 6. Rentangan Nilai yang Diperoleh peserta didik Pada Siklus Ketiga

\begin{tabular}{|l|c|c|}
\hline No & Nilai & Hasil Yang Diperoleh \\
\hline 1. & $0-60$ & 5 \\
\hline 2. & $61-70$ & 0 \\
\hline 3. & $71-80$ & 23 \\
\hline 4. & $81-90$ & 0 \\
\hline 5. & $91-100$ & 6 \\
\hline
\end{tabular}

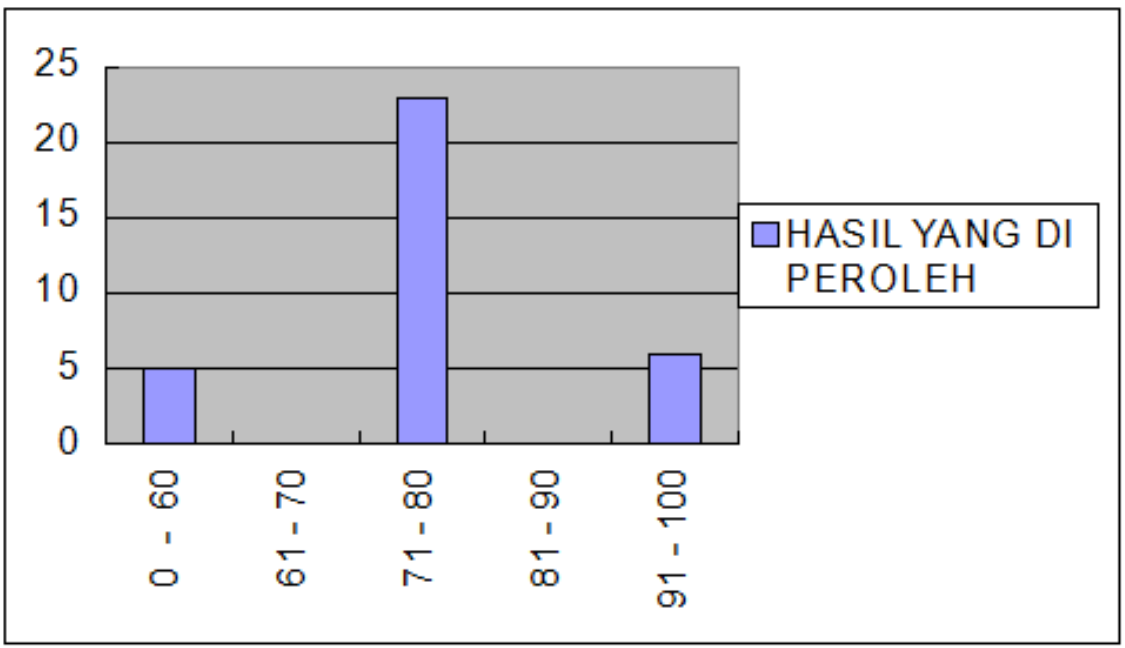

Gambar 3. Perolehan Nilai tes pada siklus 3

\section{Diskusi}

Dari hasil pengamatan dalam pelaksanaan penelitian tindakan kelas yang dilaksanakan telah memenuhi indikator keberhasilan dalam penelitan. Terbukti dengan perolehan nilai rata-rata tes akhir pada siklus pertama 65,29 meningkat pada siklus kedua dengan perolehan rata-rata nilai tes akhir 70,88 dan rata-rata pada siklus ketiga 80,58. Perobahan nilai siklus ketiga ini meningkat dengan pencapaian $18,64 \%$ dari perolehan nilai rata-rata pada tes siklus pertama. Persentase ketuntasan pada siklus pertama 64,71\% sedangkan pada siklus ketiga meningkat menjadi 83,35\%. Bearti ketuntasan yang diperoleh pada silkus ketiga mencapai $18,64 \%$ dari siklus pertama.

Pengembangan budaya literasi di sekolah SDN Gladak Anyar IV Pamekasan Keberhasilan pengembangan budaya literasi Pamekasan tercermin dari tumbuhnya minat baca anak. Ketika minat baca siswa meningkat, mereka dapat melihat bahwa anak-anak mereka bahagia, penyayang, atau berminat membaca. Dia juga menjelaskan bahwa cinta adalah apa yang disukai dan dicintai orang. Jadi, 
jika orang tersebut melakukan sesuatu yang penting baginya, dia akan bahagia tanpa hambatan dari luar (Sardiman, 2009). Menurut pengamatan peneliti, siswa SDN Gladak Anyar IV Pamekasan terlihat antusias, energik, gembira dan antusias saat mengikuti program literasi sekolah. Ini menunjukkan bahwa anak-anak bersemangat untuk melanjutkan proses literasi. Ini didasarkan pada visi Slamet dan menunjukkan beberapa indikator tentang apa yang ingin Anda lakukan, termasuk kesenangan, minat, penerimaan, dan keterlibatan siswa (Sardiman, 2009). Mempromosikan budaya literasi dan menggunakan teknologi untuk menyerap informasi. Sementara itu, penelitian ini menyoroti peningkatan minat baca oleh SDN Gladak Anyar IV Pamekasan dan hal baru yang difokuskan untuk menjelaskan dan mempelajari perkembangan budaya literasi. Alhasil, hasil pengembangan budaya literasi menunjukkan bahwa minat baca, minat baca, dan minat baca siswa dapat meningkat. Pengembangan SDN Gladak Anyar IV Pamekasan menerapkan strategi membaca seperti SQ3R, MTJ dan Minta untuk membantu sekolah, kepala sekolah dan guru memahami proses pengembangan budaya literasi.

\section{KESIMPULAN}

Dari hasi proses pembelajaran pada penelitian tindakan kelas yang dilakukan selama tiga siklus dan analisa pengamatan penulis dengan teman kolaborasi dapat di simpulkan bahwa penggunakan media kartu merah putih dapat meningkatkan hasil belajar peserta didik, hal ini dapat dilihat dari $64.71 \%$ ketuntasan pada siklus pertama, meningkat pada siklus ketiga menjadi 83.35\%.Berdasarkan hasil penelitian yang diperoleh dari penerapan media kartu merah putih pada materi operasi hitung bilangan bulat positif negatif, maka penulis berharap agar :

1. Dalam melaksanakan pembelajaran dengan materi operasi hitung bilangan bulat positif negatif diperlukan media kartu merah putih yang menunjang pembelajaran sehingga memperoleh hasil yang diharapkan.

2. Sebagai guru hendaknya memiliki kreatifitas yang dapat meningkatkan inovasi untuk menumbuhkan motivasi belajar pada peserta didik.

3. Untuk dapat memilih media kartu merah putih yang membangun karakter peserta didik dalam proses pembelajaran agar dapat diterapkan dalam kehidupan sehari-hari.

\section{UCAPAN TERIMA KASIH}

Ucapan terima kasih sangat layak disampaikan untuk semua pihak yang telah membantu dalam pengerjaan artikel ini. Baik teman, dosen, kakak, dan yang lainnya. Artikel ini dapat dibuat karena adanya bantuan mereka. Semoga artikel ini dapat bermanfaaat untuk banyak pihak.

\section{REFERENSI}

Basleman, Anisah \& Mappa, Syamsu. (2011). Teori Belajar Orang Dewasa. Bandung: PT. Remaja Rosdakarya Offset. 
Upaya Meningkatkan Hasil Belajar IPA Peserta Didik pada Masa Pandemi Covid-19 Melalui Project Based Learning di Kelas VI.C T.P. 2020/2021 SD Negeri 04 Payakumbuh, Zuharnelhas

Dahar, Ratna Wilis. 2011. Teori-Teori Belajar dan Pembelajaran. Jakarta: Erlangga

Dimyati \& Mudjiono, 2006. Belajar dan Pembelajaran. Jakarta: Rineka Cipta.

Djamarah \& Zain. (2006). Strategi belajar mengajar. Jakarta: Rineka Cipta.

Hamalik, O 2004. Proses Belajar Mengajar. Bandung: Bumi Aksara.

Hanafiah, dan Cucu Suhana. 2009. Konsep Strategi Pembelajaran. Bandung: PT Refika aditama.

Hamalik. 2012. Manajemen Pengembangan Kurikulum. Bandung: Remaja Rosdakarya

Sanjaya, Wina. (2010). Strategi Pembelajaran Berorientasi Standar Proses Pendidikan. Jakarta: Prenada Media Group.

Slavin, 1995 (dalam Isjoni, 2011:15), https://perpuskampus.com > Pendidikan

Slavin Steve, 2005, Matematika untuk Skolah Dasar. Bandung: Pakar Raya

Sudjana, Nana. 1989. Penilaian Hasil Belajar Mengajar. Bandung: Sinar Baru.

Sudjana, Nana, 1998, Dasar-Dasar Proses Belajar Mengajar, Bandung: Sinar Baru Algesindo.

Sudjana, Nana. 2005. Dasar-Dasar Proses Belajar Mengajar. Bandung: Sinar Baru Algesindo.

Trianto. 2012. media kartu merah putih Terpadu. Jakarta:PT Bumi Aksara Abidin,

Yunus. 2018. Pembelajaran Literasi Strategi Meningkatkan Kemampuan Literasi Matematika, Sains, Membaca Dan Menulis. Jakarta: Bumi Aksara. 